Veronica Vos

Master's Thesis

Spring 2016

\title{
Female Empowerment and National Poverty
}

Determining which variables contribute most to the disempowerment of women is a great challenge. In response to this challenge, numerous scholars have produced thoughtful indices meant to capture the most significant of these variables, whether they be economic, social or personal. A widely accepted explanation focuses on poverty, at the personal or household level, and the effect it has on the prevalence and severity of disempowerment. A number of scholars have also investigated the relationship between democracy and female empowerment, at the national level. Alternately, disempowerment has been named as a cause of economic stagnation in developing countries. However, almost no attention has been paid to the possible endogeneity of the relationship between national poverty and female empowerment. This study will attempt to fill two gaps in the literature: the first of which ignores national-level poverty in the discussion of empowerment; and the second of which fails to acknowledge the potential endogeneity between development and female empowerment. In other words, does national poverty contribute to female disempowerment in addition to disempowerment leading to national poverty? This paper will argue that if a country is poor, then it is more likely to maintain a system of government and resource distribution that discriminates against women. As a part of this endeavor, this paper will be putting forward a new index of empowerment, incorporating the most politically salient components of other successful indices, while adding several important variables usually excluded from these indices. Broadly speaking, the more the literature distances itself from regional, or religious, explanations for female disempowerment, the closer it gets to truly understanding the root, structural causes of this political phenomenon. Therefore, this project argues that explanations for female empowerment should look beyond common stereotypes, and focus, instead, on each country's GDP as one of the key determinants of female disempowerment.

\section{Introduction}

To begin, this analysis addresses the issue of female disempowerment, defined as the structural and social undervaluing of women as equal contributors to society and the active oppression of women and girls who wish to contribute equally. This analysis is particularly interested in those social and structural features which indicate the exclusion of women and girls from the public sphere.

With this definition in mind, this analysis intends to make three substantive contributions. First of all, a brief review of the disempowerment literature uncovers the absence of any real discussion of national-level poverty as a cause of female disempowerment. However, there is a good deal of literature 
connecting household and neighborhood-level poverty to female disempowerment. This raises the obvious question, addressed here, of the relationship between poverty and female disempowerment at the national level.

Second, this essay aims to untangle the direction of causation between the success of national economies and female disempowerment. The literature already claims that disempowerment leads to economic stagnation in the developing world, especially as a result of low labor force participation rates for women. But, this analysis will reverse this story, and investigate whether economic stagnation is actually the cause of later female disempowerment.

Finally, this analysis introduces a new and original index for measuring female disempowerment, pulling on numerous measures from alternate indices and picking only those factors that cannot be directly linked with economic outcomes. The index also includes legal indicators, which measure the status of women's legal rights in each country. The global data on female disempowerment has generally ignored legal indicators up until today, which is another oversight this essay hopes to remedy.

The structure of the essay begins with an overview of the literature on disempowerment, followed by a discussion of the hypotheses to be addressed in this paper. Then, the challenge of measuring disempowerment is addressed, leading to the operationalization of those hypotheses outlined in the previous sections. The final sections of the essay present and interpret the quantitative models at the heart of this analysis.

\section{The Literature on Disempowerment}

One of the prominent explanations for female disempowerment within the literature is household level poverty. But very little attention is paid to national-level poverty, or the way in which a system of widespread poverty affects the empowerment of women living within that society. What is more, the variables used to measure empowerment have varied widely. 
Poverty, at the individual level, is linked with disempowerment in a number of ways. For example, poor women face unique public health challenges. ${ }^{1}$ These include higher rates of maternal mortality, adolescent fertility, domestic abuse, and cognitive challenges as a result of malnourishment in childhood. ${ }^{2}$ Higher fertility rates are also widely associated with low labor force participation rates for women, ${ }^{3}$ and cognitive challenges in some communities can lead to lower returns on higher education for some women. Indeed, there has been an abundance of studies written about labor force participation rates and education enrollment, using both as measures of female empowerment. However, none of these studies analyze disempowerment to see whether the national level of analysis reflects patterns similar to small communities and individuals.

Investigations into global female labor force participation have uncovered an interesting relationship between women in the work force and a country's level of development. Indeed, the correlation is u-shaped, with those countries in the mid-range of development with the lowest female participation rates, while both highly developed and very poor countries witness high levels of female participation in the economic sector. ${ }^{4}$ Age demographics appear to function in a similar manner, with elderly and very young women often more active in the labor market, while women in the middle of their lives are less involved in the labor market than would be predicted by their education level. ${ }^{5}$ After all, education and labor force participation are cyclically linked. There is little incentive to educate women when job opportunities will not be available to them upon the completion of their education.

\footnotetext{
${ }^{1}$ Semahegn, Agumasie, and Bezatu Mengistie. "Domestic violence against women and associated factors in Ethiopia; systematic review." Reproductive health 12.1 (2015): 78.

${ }^{2}$ Lynn, Richard, and Prateek Yadav. "Differences in cognitive ability, per capita income, infant mortality, fertility and latitude across the states of India." Intelligence 49 (2015): 179-185.

${ }^{3}$ Apps, Patricia F., and Ray Rees. "Fertility, female labor supply and public policy." (2001).

Engelhardt, Henriette, and Alexia Prskawetz. "On the changing correlation between fertility and female employment over space and time." European Journal of Population/Revue européenne de Démographie 20.1 (2004): 35-62.

${ }^{4}$ Lincove, Jane Arnold. "Growth, girls' education, and female labor: A longitudinal analysis." The Journal of Developing Areas 41.2 (2008): 45-68.

${ }^{5}$ Besamusca, Janna, et al. "Working Women Worldwide. Age Effects in Female Labor Force Participation in 117 Countries." World Development 74 (2015): 123-141.
} 
Similarly, jobs created by development are unlikely to go to uneducated women. However, this cycle is particularly tragic because it affects women differently than it does men. In fact, school curriculums are often separated by gender, placing women in classes which lead to less lucrative career prospects. ${ }^{6}$

In addition, a large number of articles look at the issue of domestic violence as another form of disempowerment, investigating the effect of household and neighborhood poverty on the rates of this abuse. Many argue that there is no consistent relationship between gender violence and household poverty, in part because the data on gender violence is both inconsistent and deeply flawed. ${ }^{7}$

Nonetheless, some claim to have uncovered patterns in certain circumstances, including the rural communities of the southern United States. They claim that women in these regions, and in low-income households are far more likely to experience domestic abuse than women of the same region in highincome households. ${ }^{8}$ Others have found that poor women are significantly more likely to be murdered by their intimate partners than are rich women. ${ }^{9}$ In some regions bride-prices, or dowries, have been connected with higher rates of violence against women because, in such cases, women are being treated as property sold by one family and bought by another. ${ }^{10}$ Widening the scope of the analysis has also yielded some interesting results, showing that the socioeconomic conditions of a given

\footnotetext{
${ }^{6}$ Oztunc, Hakan, Oo Zar Chi, and Zehra Vildan Serin. "Effects Of Female Education On Economic Growth: A Cross Country Empirical Study." Educational Sciences: Theory \& Practice 15.2 (2015): 349-357. Academic Search Complete. Web. 7 Dec. 2015.

${ }^{7}$ Bamiwuye, Samson Olusina, and Clifford Odimegwu. "Spousal violence in sub-Saharan Africa: does household poverty-wealth matter?." Reproductive health 11.1 (2014): 45.

${ }^{8}$ Farber, Naomi, and Julie E. Miller-Cribbs. "Violence in the lives of rural, southern, and poor white women." Violence against women (2014).

Kocacık, Faruk, Aziz Kutlar, and Feray Erselcan. "Domestic violence against women: A field study in Turkey." The Social Science Journal 44.4 (2007): 698-720.

${ }^{9}$ Evans, Susan. "Beyond Gender: Class, Poverty And Domestic Violence." Australian Social Work 58.1 (2005): 36-43. Academic Search Complete. Web. 8 Dec. 2015.

${ }^{10}$ Hague, Gill, Ravi K. Thiara, and Atuki Turner. "Bride-price and its links to domestic violence and poverty in Uganda: A participatory action research study." Women's Studies International Forum. Vol. 34. No. 6. Pergamon, 2011.
} 
neighborhood are more highly correlated with domestic violence than are the economic conditions of individual households. ${ }^{11}$ However, measurement challenges complicate these conclusions.

Nonetheless, the policy world has expounded the virtues of micro-credit for female entrepreneurs, in an effort to open doors for women in the labor market and provide them with economic independence. At a very basic level, providing women with easier access to credit increases the probability that they will have access to a diverse diet. ${ }^{12}$ But, more broadly, the literature has found that investing in women directly does more to aid development than investing in individual men. This is likely because women are more inclined to spend the money they earn in order to provide for their family's future, while men are more inclined to invest in their own personal goals. ${ }^{13}$ However, there are also individuals who have expressed concerns about possible connections between micro-credit loans and increased domestic violence against these women by men who feel threatened by their empowerment. On the one hand, this highlights the complexity of empowerment, because it is possible for economic empowerment and physical disempowerment to coexist. But, on the other hand, critics of this approach have found that correlations between micro-credit and experiences of intimate partner violence are actually a matter of self-selection, because women who apply for micro-credit loans are often women fleeing abusive relationships, and attempting to provide for themselves financially in the absence of a partner. ${ }^{14}$ The available research thus gives reason to view with caution any attempt to incorporate the prevalence of micro-credit programs into an index of female disempowerment.

\footnotetext{
${ }^{11}$ Kiss, Ligia, et al. "Gender-based violence and socioeconomic inequalities: Does living in more deprived neighbourhoods increase women's risk of intimate partner violence?." Social science \& medicine 74.8 (2012): 1172-1179.

${ }^{12}$ Malapit, Hazel Jean L., and Agnes R. Quisumbing. "What dimensions of women's empowerment in agriculture matter for nutrition in Ghana?." Food Policy 52 (2015): 54-63.

${ }^{13}$ Rehman, Huma, Amani Moazzam, and Nighat Ansari. "Role Of Microfinance Institutions In Women Empowerment: A Case Study Of Akhuwat, Pakistan." South Asian Studies (1026-678X) 30.1 (2015): 93-111. Academic Search Complete. Web. 7 Dec. 2015.

${ }^{14}$ Bajracharya, Ashish, and Sajeda Amin. "Microcredit And Domestic Violence In Bangladesh: An Exploration Of Selection Bias Influences." Demography 50.5 (2013): 1819-1843. EconLit with Full Text. Web. 8 Dec. 2015.
} 
Some scholars have begun by measuring empowerment based on survey data. These results have demonstrated, among other things, that public opinion regarding the role of women is linked with a country's GDP, although the relationship appears to be endogenous and it is not easy to determine whether opinions about empowerment lead to economic success, or economic success leads to more open minded acceptance of empowerment. ${ }^{15}$ Either way, survey data is notoriously challenging to analyze because individuals often frame their answers based upon what they feel is externally appropriate, rather than what they actually believe. This could mean that respondents appear more accepting than they actually are because they do not wish to be judged poorly by the interviewer. But, it could also mean that respondents appear more closed-minded because they want to fall into line with local culture. It is impossible to tell the difference. For this reason, event-based statistics are usually the more reliable option for the proper analysis of disempowerment.

Indeed, there is a recent trend in the measurement of empowerment which uses the gap between genders when it comes to healthcare, ${ }^{16}$ education or wages as a more accurate portrayal of the ways in which poverty affects women differently than men. Once such index is called the Gender Inequality Index (GII) or, in its previous form, the Gender Empowerment Measure (GEM). It is based on the UN's measures of empowerment and includes maternal mortality, adolescent birth rate, the share of seats in parliament held by women, the percentage of women with a secondary education and the female labor force participation rate. ${ }^{17}$ Another, called the Gender Development Index (GDI), pulls on

\footnotetext{
${ }^{15}$ Owen, A. L. and You, R. (2009), Growth, Attitudes towards Women, and Women's Welfare. Review of Development Economics, 13: 134-150. doi: 10.1111/j.1467-9361.2008.00466.x

${ }^{16}$ Barthold, Douglas, et al. "Analyzing Whether Countries Are Equally Efficient At Improving Longevity For Men And Women." American Journal Of Public Health 104.11 (2014): 2163-2169. SPORTDiscus with Full Text. Web. 7 Dec. 2015.

${ }^{17}$ Ruppanner, Leah E. "Cross-national reports of housework: An investigation of the gender empowerment measure." Social Science Research 39.6 (2010): 963-975.
} 
measures of the Human Development Index (HDI), separated by gender. ${ }^{18}$ This includes life expectancy, education variables and income per capita for the female population.

Others have attempted to measure disempowerment based upon social restrictions which prevent women from making decisions regarding the path of their own life. ${ }^{19}$ One such measure is called the Full Rights Realization Rate (FRRR), and measures the rights granted to women in their early years and the effect this has on their later success. ${ }^{20}$ Unfortunately, this dataset focuses on the districts of India, rather than the world at large. Finally, another index compiled by Charmes and Wieringa incorporates legal measures into the index for empowerment, even if only for the African continent. ${ }^{21}$ This approach, however, has laid the foundation for the index presented in the methodology segment of this paper. For, there remains a gap in the literature when it comes to connecting legal disempowerment to national poverty, a gap that this study hopes to fill. ${ }^{22}$

Yet, this study hopes to go beyond just how disempowerment is connected with poverty. For, there are two bodies of literature which address disempowerment on the national scale, the scale which is of most interest to this study. The first deals with democracy as both a cause and an effect of empowerment. Indeed, the literature tells us that female empowerment is intimately linked with the success of a country's democracy. ${ }^{23}$ But, the direction of causation in this relationship is not clear. The second body of literature shows a link between GDP and empowerment, but only looks at

\footnotetext{
${ }^{18}$ Klasen, Stephan, and Dana Schuler. "Reforming The Gender-Related Development Index And The Gender Empowerment Measure: Implementing Some Specific Proposals." Feminist Economics 17.1 (2011): 1-30. EconLit with Full Text. Web. 10 Dec. 2015.

${ }^{19}$ Mishra, Ankita. "Multidimensional measures of female disempowerment." Social Indicators Research 119.3 (2014): 1393-1410.

${ }^{20}$ Chaudhuri, Sanjukta. "A Life Course Model of Human Rights Realization, Female Empowerment, and Gender Inequality in India." World Development 52 (2013): 55-70.

${ }^{21}$ Charmes, Jacques, and Saskia Wieringa. "Measuring women's empowerment: an assessment of the genderrelated development index and the gender empowerment measure." Journal of Human Development 4.3 (2003): 419-435.

22 Upadhyay, Ushma D., et al. "Women's empowerment and fertility: A review of the literature." Social Science \& Medicine 115 (2014): 111-120.

${ }^{23}$ Wyndow, Paula, Jianghong Li, and Eugen Mattes. "Female empowerment as a core driver of democratic development: A dynamic panel model from 1980 to 2005." World Development 52 (2013): 34-54.
} 
empowerment leading to an increase in GDP. ${ }^{24}$ This essay attempts to look at this relationship from the opposite direction and ask whether a decrease in GDP actually leads to disempowerment.

Finally, this study hopes to move beyond regional or religious explanations for

disempowerment. Many western policy makers consider the Middle East, Africa or the Muslim world to have the highest rates of disempowerment. However, gender violence, and other measures of disempowerment, are prevalent all over the world. ${ }^{25}$ This includes countries which most scholars would consider advanced. It is also worth noting that women are not generally helpless victims. Impoverished and socially restrained women can be creative, inventive, and involved in the changing of their own destinies. ${ }^{26}$ And in many places, change has already started; the gap between labor force participation for rich and poor women is shrinking, and more women now have access to higher education. ${ }^{27}$ But, in order to further this change, it is imperative that we understand the root causes of the problem.

\section{Disempowerment Hypotheses}

The disempowerment literature states that the lower the income of a household, or the lower the average income of a neighborhood, the more likely it is that the women in either place will be systematically disempowered. To repeat, disempowerment is being defined here as the structural and social undervaluing of women as equal contributors to society and the active oppression of women and girls who wish to contribute equally. Extrapolating from this literature, the central hypothesis of this essay ( $\mathrm{H} 1$ ) looks at the national level of analysis. For, it seems plausible that the size of a country's total

\footnotetext{
${ }^{24}$ York, Richard, and Shannon Elizabeth Bell. "Life satisfaction across nations: The effects of women's political status and public priorities." Social science research 48 (2014): 48-61.

${ }^{25}$ Rivera-Rivera, Leonor, et al. "Prevalence and determinants of male partner violence against Mexican women: $\mathrm{A}$ population-based study." salud pública de méxico 46.2 (2004): 113-122.

${ }^{26}$ Al Rashedi, Noura, et al. "Social Marketing, Education And The Female Workforce: A Comparison Of United Arab Emirates And Kingdom Of Saudi Arabia." Middle East Journal Of Business 10.1 (2015): 39-49. Business Source Complete. Web. 7 Dec. 2015.

${ }^{27}$ Abramo, Laís, and María Elena Valenzuela. "Women's labour force participation rates in Latin America." International Labour Review 144.4 (2005): 369-400.
} 
GDP will establish a national-level culture of empowerment. After all, the distribution of resources is the primary determinant of much social behavior, and it is expected that its effects will bleed over into the treatment of women within each state's borders. Indeed, with limited resources distributed sparsely across a country's population, latent sexism is given a chance to assert itself, with the undervaluing of female life. ${ }^{28}$ This could take the extreme forms of domestic violence or female infanticide, ${ }^{29}$ but will more often take the subtler forms of the undernourishment of women or their exclusion from state services, including education. This leads to the baseline hypothesis of this analysis:

H1: The lower a country's total GDP, the more likely it is that the women of that country are systematically disempowered.

The literature also has a lot to say about the connection between democracy and female empowerment. This branch of the literature joins the question of disempowerment with the already tangled field linking democracy and development. After all, given the widely studied link between democracy and development, it follows that democracy might play some role in empowerment, simply because of its correlation with development. Even so, there is another causal pathway that could be connecting democracy and empowerment, because democracy opens government to the opinions and activism of the people, allowing women to petition for better treatment and more substantial rights. As such, there is reason to include both economic success and democracy in the same hypothesis, in order to determine the strength of the economic effect, even when democracy is being held constant. This leads to a second hypothesis:

H2: Those countries that are less democratic are more likely to disempower their female citizens.

\footnotetext{
${ }^{28}$ My this logic, it is equally true that other social ills such as racism or classism, could rise to the surface under these conditions, but this analysis will focus on measuring this phenomenon for women of all races and classes within each society.

${ }^{29}$ Grech, Victor. "Evidence of economic deprivation and female foeticide in a United Nations global births by gender data set." Early human development 91.12 (2015): 855-858.
} 
The third hypothesis of this analysis broadens the model to include geography and looks to incorporate regional variation into the question of female disempowerment. After all, certain regions of the world, such as the Middle East and Africa, are often more associated with the disempowerment of women. What is more, female infanticide in China and India have gotten much attention in recent years. Even so, this analysis expects to see the opposite of what is theorized in the literature, with other population variables having much greater explanatory power than "region" when it comes to female disempowerment. Indeed, region is too imprecise a measure of variation, and therefore:

H3: Region should have no effect upon female disempowerment when controlling for national wealth, and a country's level of democratization.

The fourth hypothesis of this analysis pulls upon variables relating to the characteristics of a country's general population. After all, given that the core hypothesis for this analysis is making an assumption about the opinions and behavior of a country's population, as affected by poverty, it also makes sense to incorporate other identifying factors of a country's population, in order to help isolate the effect of poverty. The main population feature included here is diversity within the population. It stands to reason that the linguistic and ethnic heterogeneity of a country will affect the disempowerment of women within that country. This can be explained by saying that diversity divides the population into segments and makes it harder to generalize about shared expectations and behaviors across the whole state. However, greater diversity makes it easier to dehumanize and mistreat women who fall into different social or ethnic groups. This leads to a fourth hypothesis:

H4: The more diverse a country, the more likely it is that the women within that country are disempowered.

In addition to a country's level of diversity, the dominant religion within a country has been given a lot of credit, and blame, both within the literature and within the general media, for determining the way in which a country treats its female population. Muslim countries, in particular, have been 
singled out for their often severe manifestations of female disempowerment. Similarly, countries dominated by "traditional" or unorganized religions have been the focus of many campaigns against disempowerment, particularly along the front of female genital mutilation. ${ }^{30}$ Finally, some East Asian religions have been criticized for their association with female infanticide and sex selective abortions. Countries dominated by either Catholic or Christian populations have been exempt from these critiques regarding disempowerment. In the face of these misleading generalizations, this analysis will argue the opposite of the conventional wisdom, by positing that any perceived correlation between the beliefs of certain religions and female disempowerment, is not an accurate portrayal of reality (H5).

H5: The predominant religion in a country should have no effect upon the disempowerment of women in that country when the levels of diversity, democracy and economic development within a country are held constant.

With this said, there is still another variable which could be helpful when it comes to explaining the global pattern of female disempowerment, and this variable is economic inequality. Indeed, inequality probably functions in ways similar to diversity, although it cuts across lines of social identity, it still serves to alienate members of different economic classes. The literature has already noted the mistreatment and abuse of women of lower classes by those who are more powerful, and inequality serves to compound these effects. As such, inequality is expected to play an important part in explaining female disempowerment.

H6: The more economic inequality present within a country, the more likely it is that the women of that country are disempowered.

The general literature also calls for the addition of one more variable related to the social distribution of a country's population, and this variable is urbanization. For, it is plausible to see a more

\footnotetext{
${ }^{30}$ Setegn, Tesfaye, Yihunie Lakew, and Kebede Deribe. "Geographic Variation and Factors Associated with Female Genital Mutilation among Reproductive Age Women in Ethiopia: A National Population Based Survey." PloS one 11.1 (2016): e0145329.
} 
heavily urbanized population as more able to take action towards a shared political goal. In other words, the close proximity of individuals reduces the cost and effort required for collective action in favor of political rights and female empowerment. Therefore, despite structural impediments to empowerment, such as poverty and political systems, and social impediments to empowerment, such as diversity and inequality, there is reason to believe that urbanization could still be a force for potential empowerment.

H7: The less urban a country, the more likely it is that the women living in that country will be disempowered.

The final, remaining hypothesis returns to the basic model of national poverty and female disempowerment, but explores the additional dimension of time. In short, this final hypothesis states that the effect of national poverty on female disempowerment will still be felt several decades later, and that previous eras of economic success or failure have helped to mold the treatment and status of women in the modern world.

H8: The more impoverished a country was in the previous decade, the more likely it is that the women of that country will be disempowered in the current decade.

I now turn to operationalizing these hypotheses, discussing measures and methods, and the statistical estimations used to test these hypotheses.

\section{Measuring Disempowerment}

The goal of this analysis is to present a snapshot of women's disempowerment across the globe in the early years of the twenty-first century, and to explain the cross-national differences observed in that snapshot. This analysis is not interested in tracking the changes in disempowerment over time, but simply in establishing a link between national poverty and female disempowerment by looking at the world in cross-section, using data from roughly 130 countries. This decision was driven largely by data availability, because very few measures of female disempowerment are updated annually, instead they 
are updated at sporadic intervals that cannot reliably be paired with the other variables in this analysis. Therefore, even though GDP is measured quite regularly and dependably, each country's total GDP, averaged over a recent period of fifteen years, will be used as the measure for national poverty in most of the models, and as the chief independent variable in this analysis. The measurement of the dependent variable is less straightforward.

The process of deciding which variables to include in the index for this analysis was long, complicated, and will be described in full detail in the following pages, but the final index includes only five of the many possible variables discussed below. These five variables are adolescent birth rate, share of seats in parliament held by women, the gender gap when it comes to mean years of schooling, women's legal rights when it comes to family law and women's legal rights when it comes to property law. These variables are restated explicitly in Table 1 , and are the only variables included in the final index for this analysis.

Table 1. Disempowerment Index

\begin{tabular}{|c|c|c|c|c|c|}
\hline Variables & $\begin{array}{l}\text { Adolescent } \\
\text { Birth Rate }\end{array}$ & $\begin{array}{l}\text { Share of Seats in } \\
\text { Parliament held } \\
\text { by men }\end{array}$ & $\begin{array}{l}\text { Gender gap in } \\
\text { mean years of } \\
\text { schooling }\end{array}$ & $\begin{array}{l}\text { Women's } \\
\text { Legal Rights in } \\
\text { Family Law } \\
\end{array}$ & $\begin{array}{l}\text { Women's } \\
\text { Legal Rights in } \\
\text { Property Law }\end{array}$ \\
\hline Description & $\begin{array}{l}\text { Births per } \\
1000 \text { women } \\
\text { aged } 15-19\end{array}$ & $\begin{array}{l}\text { Percentage of } \\
\text { seats held by } \\
\text { women, } \\
\text { subtracted from } \\
100 \text { to } \\
\text { demonstrate } \\
\text { disempowerment }\end{array}$ & $\begin{array}{l}\text { Difference } \\
\text { between } \\
\text { years of } \\
\text { school } \\
\text { actually } \\
\text { completed for } \\
\text { men and } \\
\text { women }\end{array}$ & $\begin{array}{l}\text { Index } \\
\text { measuring } \\
\text { women's } \\
\text { rights in } \\
\text { family law, } \\
\text { both in law } \\
\text { and practice }\end{array}$ & $\begin{array}{l}\text { Index } \\
\text { measuring } \\
\text { women's } \\
\text { rights in } \\
\text { property law }\end{array}$ \\
\hline $\begin{array}{l}\text { Variable } \\
\text { Mean }\end{array}$ & 51.6 & 79.2 & .82 & 2.1 & .74 \\
\hline $\begin{array}{l}\text { Standard } \\
\text { Deviation } \\
\text { (min, max) }\end{array}$ & $\begin{array}{l}43.3 \\
(.6,204.8)\end{array}$ & $\begin{array}{l}11.3 \\
(42.5,100)\end{array}$ & $\begin{array}{l}1.11 \\
(-2.3,3.9)\end{array}$ & $\begin{array}{l}1.1 \\
(0,4)\end{array}$ & $\begin{array}{l}.92 \\
(0,2)\end{array}$ \\
\hline
\end{tabular}

As already mentioned, the literature includes multiple indices for the measurement of empowerment. However, only two of these indices have a global reach: the Gender Development Index 
(GDI) and the Gender Inequality Index (GII), both produced by the United Nations Development Program (UNDP). Both of these indices are only re-published every few years. The index used in this study will pull on the strengths of both indices, while adding additional variables, to ensure that the resulting index provides a more comprehensive picture of disempowerment's many facets, and includes only noneconomic variables in order to prevent endogeneity with the model's independent variable. ${ }^{31}$

The GII index covers 188 countries and includes maternal mortality, the adolescent birth rate, and the share of seats in parliament held by women. It also includes the percentage of the female population with a secondary education and the female labor force participation rate. Indeed, there are compelling reasons for including each and every one of these five factors as measures of empowerment, but some are more helpful than others for the purpose of this study. First of all, the maternal mortality rate can easily be linked with a country's economic success and a woman's ease of access to medical care. Because only women are affected by this phenomenon, and there is no corresponding measure of male access to healthcare, it is impossible to tell whether these numbers are the result of discrimination, or simply the result of poverty and poor health infrastructure. As such, this variable cannot be included in this study's index.

It is harder to connect adolescent birth rates with economic development, for although wealthier nations often have better birth control offerings, those places with the highest adolescent birth rates are also those places where child marriage is considered acceptable, and this second social pattern does not necessarily correspond with any particular economic patterns. What is more, this measure of adolescent birth rate is significantly more dependable than any variable of child marriage, although both variables do similar work to measure the early disempowerment of young women. But, governments have every incentive to under-report child marriages, or ignore "traditional" marriages which take place outside of their control, making any such measure unreliable. Thus, adolescent birth

\footnotetext{
${ }^{31}$ Only the most recent statistics included in each of these indices will be incorporated into this analysis.
} 
rate will be the first variable included in this study's final index, as a measure of the early imposition of male-dominated sexual norms onto the young women of a country.

Third, the share of seats in parliament is nearly impossible to link with economic development. The only challenge with this measure is answering whether the number of women in parliament actually indicates female empowerment, by way of substantive representation, or is simply the result of the global push for female quotas in legislatures and the push for descriptive representation. ${ }^{32}$ This debate rages on in the literature ${ }^{33}$ and many authors argue that female representation in parliament sets a standard for female ambition and self-esteem, but rarely results in substantive policy changes that favor women. Nonetheless, this paper will err on the side of inclusion, arguing that not all women in legislative positions are there as a result of quotas and that quotas themselves may even be indicators of empowerment. As such, the share of seats in parliament held by women will represent the second variable included in this study's final index.

The fourth variable of the GII measures the percentage of the female population that receives a secondary education. However, the education measures used in the GDI are simpler, more effective measures of a country's educational infrastructure. The GDI measures education based upon the expected years of schooling for women, compared to men, in addition to the mean years of schooling expected for women, compared to men. The measure for expected years of schooling reflects government projections, based on official regulations and education funding. The measure for mean years reflects the actual years of schooling most citizens end up completing. In almost every case, reality is lower than expectations. As such, for the purpose of this analysis, the more interesting measure, of

\footnotetext{
32 Wängnerud, Lena. "Women in parliaments: Descriptive and substantive representation." Annual Review of Political Science 12 (2009): 51-69.

Phillips, Anne. The politics of presence. Clarendon Press, 1995.

${ }^{33}$ Bauer, Gretchen, and Jennie E. Burnet. "Gender quotas, democracy, and women's representation in Africa: Some insights from democratic Botswana and autocratic Rwanda." Women's Studies International Forum. Vol. 41.

Pergamon, 2013.
} 
these two, is the mean number of years spent in school. This variable provides the broadest picture of the quantity of education. Therefore, this gap, between the mean years of schooling for men and for women, will be included as the index's third variable.

In order to get a sense for the quality of a country's education, UNESCO literacy data was included in the early iterations of this study. However, further investigation and research revealed that the global data on literacy falls into two categories. For most countries in the world, literacy data can be found divided by gender. For the world's most developed countries, however, no such data exists. For these cases, data on school testing results and the quality of literacy are widely available, but illiteracy is never mentioned and widely ignored. There is a growing political initiative for developed countries to acknowledge the sad truth that illiteracy still exists within their borders. Even so, this data is not available at this time, which limits this index's education measure to simply mean years of schooling. ${ }^{34}$

The fifth and final variable included in the GII measures a country's labor force participation rates for both women and men. However, as has already been mentioned, the literature has uncovered a u-shaped relationship between female labor force participation and economic development. For this reason, this variable is too closely linked with economic outcomes and will not be included in the final index for this study.

Moving onto the GDI, its measures for education have already been mentioned, but the full index also includes measures for female life expectancy, as well as income per capita within the female population. Focusing, first, on female life expectancy, the numbers show that women have a longer life expectancy than men, on average, in virtually every country in the world. This, unfortunately, does not include the figures on infanticide or the kind of discrimination against female children, which leads to childhood death and decline, as discussed in Amartya Sen's work on missing women. ${ }^{35}$ Therefore, a raw

\footnotetext{
${ }^{34}$ This choice of education measure is drawn from: McGuire, James W. Wealth, health, and democracy in East Asia and Latin America. Cambridge University Press, 2010.

${ }^{35}$ Sen, Amartya. "More than 100 million women are missing." The New York Review of Books (1990).
} 
measure of the life expectancy gap serves little purpose as a measure of discrimination and will not be included in the final index of this analysis.

Still pulling from the GDI, this leaves only income per capita within a country's female population as a potential variable. Now, it is fair to describe the link between the gender income gap and a country's level of development as undertheorized. For, although income is quite obviously linked with economics, the literature has yet to provide any theory as to why the income gap should be linked with economic outcomes. Indeed, in early versions of this analysis, income gap was included as a measure of female disempowerment. However, diagnostic statistical analyses quickly revealed that a country's level of development and the gender income gap are, in fact, linked. As such, while this variable appears theoretically appropriate for inclusion in the index, it has been excluded from the final index used in this analysis.

To recap, this leaves a new index with variables for adolescent birth rate, share of seats in parliament held by women, (both pulled from the GII) and the gender gap when it comes to mean years of schooling (pulled from the GDI). However, these are not the only variables that this essay will be including in its final index. This study will also be including several variables measuring the status of women in a country's legal system.

The first such variable measures the status of women's rights in family law. The scale was developed by Rose McDermott in 2011 for the WomenStats project and assigns countries an integer score from zero to four, based upon both the actual status of family laws within a country, and the implementation of these laws. Included in this measure is a conglomeration of each country's legal marriage age, female consent to marriage, women's access to divorce, laws against marital rape, abortion access, child custody rights for women and inheritance rights for women. A zero is coded as the 
best assurance of women's rights in family law, with four as the worst assurance. ${ }^{36}$ The data for this index is pulled from recent history, and does not specify dates for its conclusions but puts forward scores that represent the general status of women in the modern world when it comes to family law.

The same is true for the second legal scale, which measures the status of women's rights in property law. This scale was developed by Valerie Hudson for the WomenStats project in 2015 and scores countries on an integer scale from zero to two based upon the legal rights of women in terms of property rights. Each coding decision was based upon women's access to land ownership, access to loans, access to credit and ease of business ownership. A zero represents the most widespread access to property ownership for women, a two indicates that women are barred from most forms of property ownership.

There is no current theory connecting either of these legal variables to economic development and they serve as useful measures of the legal, formalized rights of women in a given country. Even so, each of these measures captures minimal variation between countries. For this reason, they cannot stand as measures on their own, but help to strengthen the picture of discrimination compiled in this study's final index. A detailed description of how this index was compiled can be found in the next section.

\section{Factor Analysis}

The careful compilation of this index was the first step towards building a model for this analysis. The process began with five variables: the adolescent birth rate, the share of seats in parliament held by women, the gender gap in mean years of schooling, the family law index and the property law index. However, in order to ensure that higher values for every variable indicated

\footnotetext{
${ }^{36}$ Panda, Pradeep, and Bina Agarwal. "Marital violence, human development and women's property status in India." World Development 33.5 (2005): 823-850.
} 
disempowerment, rather than the opposite, it was necessary to reverse the parliament variable and include, instead the share of seats in parliament held by men.

Now, simply adding the values of these variables together to create an additive index would result in too much variation (with a range stretching well above 100) and make the comparison of countries more difficult. An additive index would also fail to acknowledge that some of these values carry more weight than others when it comes to determining whether the women of a country are disempowered. As such, factor analysis was employed to determine what weighting of these five variables best explains their covariation. Specifically, this index was derived using an exploratory factor analysis with a varimax rotation. Using this method showed that the five variables from this index all behave in similar ways, indicating that one single factor, disempowerment, could be underlying the data trends for all five variables. Using a varimax rotation simply brought the weighting coefficients closer to explaining more of the covariance between these variables, explaining about $96 \%$ of their covariance. The coefficients from this factor analysis were then used to weight the data, which was finally added into a continuous index ranging from about -2 to 2 , with positive values indicating disempowerment and negative values indicating empowerment.

\section{Table 2 Compiled Index Summary}

\begin{tabular}{|l|l|}
\hline Average Score & Standard Deviation (Min, Max) \\
\hline Approximately zero & $0.90(-1.5,1.9)$ \\
Examples: (Algeria, Bolivia, Chile, El Salvador, & Examples: (Denmark/Norway/Sweden, \\
Honduras, Laos, Mexico, Nicaragua, Rwanda) & Chad/Democratic Republic of Congo/Niger) \\
\hline
\end{tabular}

Brief summary statistics for the final index are displayed in Table 2. The average score for the index comes very close to zero, nearly the midpoint between the extreme scores. Also included in the table are examples of countries which fall closest to the average score, the minimum score and the maximum score. Indeed, these examples help to demonstrate that the index accurately reflects general impressions of disempowerment around the world. 


\section{Additional Independent Variables}

In addition to this index, the models of this study will include a number of independent variables of secondary importance. The first is democracy. The argument within the literature states that a democratic regime is more likely to protect the rights of its citizens, including women. Democracy is also a system of government in which all citizens are more capable of lobbying the government for an improvement in their living standards or inclusion in the workings of government. This is to say nothing of voting, from which women are still excluded in a number of semi-democracies, but still serves as the hallmark of popular inclusion in government. As such, it could be argued that democracy leads to empowerment, regardless of a country's economic status. The scale used to measure democracy will be the Polity IV index, and each country's score in this analysis represents the average score for the years 2000-2015. This scale is based upon the "subjective assessment of three measures," as determined by a team of experts: 1) "the openness and competitiveness of the recruitment of the chief executive," 2) "constraints on the authority of the chief executive," and 3) "political participation and opposition." 37 These measures are then weighted and scaled from +10 to -10 , with a +10 being the most democratic and -10 being the least democratic, although $a+6$ is typically the lowest value allowed for a country to be considered a democracy.

Second, a set of eight dummy variables will be included to represent different regions of the world. After all, there is an argument that certain parts of the world, particularly the Middle East and Africa, mistreat and disempower women more than others. These variables, as coded by James W. McGuire, have been included in an effort to refute one type of cultural explanation for female

\footnotetext{
${ }^{37}$ McGuire, James W. Wealth, health, and democracy in East Asia and Latin America. Cambridge University Press, 2010.
} 
disempowerment. ${ }^{38}$ Luckily, region is time invariant, making it an easy inclusion into a cross-sectional analysis.

The next set of secondary variables for this analysis aim to measure a country's diversity. In order to do so, two measures for ethnic and linguistic fractionalization have been pulled form Alesina's data on fractionalization. ${ }^{39}$ These measures capture how many different languages are spoken and how many people identify with distinct ethnic groups within a country, and although no time period is specified in the data, it is safe to say that these scores represent an accurate snapshot of diversity in the modern world. More specifically, these scores vary from 0 to 1 , with higher decimals indicating higher levels of fractionalization. The same theory connects both of these measures to female disempowerment. Diversity of either kind divides society into groups and sets the stage for latent sexism to play a part in the dehumanizing of other ethnicities or linguistic communities. Indeed, violence and discrimination against women are easily justified by using the excuse of "otherness."

The fifth additional variable of this analysis aims to address the issue of a country's predominant religion. Too often, it is argued that certain religions, particularly Islam, sanction the oppression of women. According to this same argument, a country's religion directly determines the gender expectations within each society. However, a series of dummies for the world's major religions will be included in this analysis, in an effort to demonstrate that economic factors are far more influential than religious ones when it comes to female disempowerment. The data for this measure will also be pulled from Alesina's data on fractionalization, and once again represents a snapshot of religious diversity in the early years of this century, because it is safe to assume that the predominant religion of a country does not change frequently. ${ }^{40}$

\footnotetext{
38 The eight dummies included for region are: Industrialized Nations, the Soviet Bloc, the Middle East, Africa, Latin America and the Caribbean, South Asia, East Asia, South East Asia and the Pacifica Islands ${ }^{39}$ Alesina, Alberto, et al. "Fractionalization." Journal of Economic growth 8.2 (2003): 155-194.

40 The seven dummies included for religion are: Catholic, Muslim, Christian, Hindu, Jewish, East Asian religions, Traditional/Unorganized religions/Atheism
} 
Another independent variable will be included for economic inequality, measured using the World Bank's records of Gini coefficients, and averaged across the years from 2000 to 2015. This measure reflects the proportion of a country's wealth that is controlled by the elite, compared with the proportion of the country's wealth controlled by the most impoverished. Higher values, on a scale from 1 to 100 , indicate greater inequality. The argument here is similar to that made for diversity. The greater the inequality within a country, the easier it is to dehumanize poor women, while placing wealthy women on pedestals of morality. Furthermore, the poor women of highly unequal countries are often too preoccupied with providing for themselves and their families to be concerned with issues of political rights, or education. As a result, inequality could be linked with disempowerment and must be held constant in the model.

Additionally, a final independent variable will be included for urbanization, based upon the World Bank estimates of the percentage of the population living in urban areas, and once again averaged across the years 2000 to 2015 . The definition of an urban area differs based up the country in question and the standards set in their statistics reports. Nonetheless, the theory connecting urbanization to empowerment states that when a population is more concentrated in urban centers it is easier for women to petition for their rights and demonstrate their competence as members of the new, urbanized economy. Therefore, urbanization could be linked with empowerment and must be held constant in the model.

Table 3. Summary Statistics for Independent Variables

\begin{tabular}{|l|l|l|l|l|l|l|l|}
\hline $\begin{array}{l}\text { Variable } \\
\text { Name }\end{array}$ & $\begin{array}{l}\text { GDP } \\
\text { (logged) }\end{array}$ & Democracy & Region & $\begin{array}{l}\text { Diversity } \\
\text { (Ethnic/Linguistic) }\end{array}$ & Religion & Inequality & Urbanization \\
\hline Average & 24.3 & 3.6 & NA & $.45 / .402$ & NA & 39.9 & 55.2 \\
\hline $\begin{array}{l}\text { Standard } \\
\text { Deviation } \\
\text { (min, max) }\end{array}$ & $\begin{array}{l}(19.8, \\
\text { 30.2) }\end{array}$ & $\begin{array}{l}(-10,10) \\
\text { (eight }\end{array}$ & $\begin{array}{l}\text { regional } \\
\text { dummies) }\end{array}$ & $\begin{array}{l}.255 / .284 \\
(0 / .002, .93 / .92)\end{array}$ & $\begin{array}{l}\text { (seven } \\
\text { religious } \\
\text { dummies) }\end{array}$ & $\begin{array}{l}8.7 \\
(21,62)\end{array}$ & $\begin{array}{l}22.8 \\
(9.6,100)\end{array}$ \\
\hline
\end{tabular}




\section{Operationalized Hypotheses}

This section will now outline the basic structure of the models included in the final statistical analysis for this paper. Essentially, this section unites the formal hypotheses outlined above, with the practical measurements used for each variable, and presents each hypothesis as a unique equation.

To begin, the first hypothesis and baseline model for this analysis is built to demonstrate that a country's level of economic development, measured using the log of average total GDP over the fifteen year period from 2000 to $2015,{ }^{41}$ will predict the level of female disempowerment within a country:

$$
\text { disempowerment index score }=K+B_{1}(\log \text { mean } G D P)+\varepsilon
$$

However, it is wise to build upon this baseline model, in order to test whether the results are robust to the inclusion of other variables that have been theorized to affect disempowerment within the literature. The most prominent alternate variable is level of democracy, measured using the Polity scores from each country, and averaged from the year 2000 until 2015, which leads to the following model:

$$
\text { disempowerment index score }=K+B_{1}(\log \text { mean GDP })+B_{2}(\text { Polity })+\varepsilon
$$

Next, this analysis adds regional dummies to the model. After all, the general literature expects to see the Middle Eastern, African and Asian regions with higher levels of female disempowerment. ${ }^{42}$ However, this analysis hopes to throw these conclusions into doubt by exploring more specific factors which differentiate regions. But first, the third model explores this regional relationship, while also incorporating democracy and GDP.

disempowerment index score $=K+B_{1}(\log$ mean GDP $)+B_{2}($ Polity $)+b_{3}$ (Regional dummies $)+\varepsilon$

\footnotetext{
41 The log of GDP was a necessary alteration to avoid the high skewness for the raw variable of GDP.

42 It is worth noting that the dummy for industrialized countries incorporates successful European and North American countries into the same variable, along with Australia.
} 
Alternatively, other variables that might affect the relationship between national wealth and female disempowerment, and also speak to regional idiosyncrasies, include the population variables for ethnic and linguistic diversity, as well as the predominant religion of a country. These identifying factors were added to the model in stages, starting with ethnic and linguistic diversity, and measured using Alesina's indices on ethnic and linguistic diversity:

disempowerment index score $=K+B_{1}(\log$ mean GDP $)+B_{2}$ (Polity) $+b_{3}($ Ethnic diversity $)+b_{4}$ (Linguistic diversity) $+\varepsilon$

Religion (also sourced from Alesina's data on diversity) was then incorporated into the model as a series of dummies:

disempowerment index score $=K+B_{1}(\log$ mean GDP $)+b_{2}$ (Polity) $+b_{3}$ (Ethnic diversity) $+b_{4}$ (Linguistic diversity) $+b_{5}$ (religious dummies) $+\varepsilon$

This leaves one further attribute of a country's social hierarchy for inclusion in the model, in addition to those already mentioned: inequality, as measured by the World Bank's Gini coefficients. disempowerment index score $=K+B_{1}(\log$ mean GDP $)+B_{2}($ Polity $)+b_{3}$ (Ethnic diversity) $+b_{4}$ (Linguistic diversity) $+b_{5}$ (religious dummies) $+b_{6}$ (average Gini coefficient) $+\varepsilon$

Now, it is with confidence in these initial hypotheses, and their effect upon a country's level of disempowerment, that this analysis moves forward to an alternate measure of location, with the hope of capturing still more nuance, not adequately communicated by simple regional distinctions. Indeed, urbanization, or the percentage of a population which lives in urban areas, is expected to capture a more liberal culture that thrives in urban areas due to the ease with which ideas are transferred and the frequency with which like-minded individuals can organize to promote their interests and rights. 
disempowerment index score $=K+b_{1}(\log$ mean GDP $)+b_{2}$ (Polity) $+b_{3}$ (Ethnic diversity) $+b_{4}$

(Linguistic diversity) $+b_{5}$ (religious dummies) $+b_{6}$ (average Gini coefficient) $+b_{7}$ (percentage of population living in urban areas) $+\varepsilon$

Since the non-integer dependent variable varies continuously between -3 and +3 , the appropriate model specification happens to be OLS regression. As such, with the models specified and the statistical method chosen, the next sections turns to an empirical analysis.

\section{Disempowerment Results}

The first stage of this statistical analysis explores bivariate relationships between the variables. Indeed, a correlation matrix reveals that the relationships between each of the variables mentioned above and the disempowerment index all trend in the directions originally theorized. In other words, disempowerment increases as diversity and inequality increase, while disempowerment decreases as democracy, urbanization and national wealth increase. The exact coefficients of these correlations are displayed in the upper portion of Table 4.

Similarly, the dummy variables for religion and region are displayed in the lower portion of Table 4, and show that Islamic, Middle Eastern and East Asian countries are most strongly correlated with disempowerment. However, the upcoming multivariate analysis will identify weaknesses in these correlations and draw attention to a more important variable contributing to female disempowerment, specifically the strength of the national economy. 
Table 4: Correlation Matrix

\begin{tabular}{|c|c|c|c|c|c|c|c|}
\hline & Index & GDP & Democracy & Ethnicity & Language & Gini & Urban \\
\hline Index & 1.0 & & & & & & \\
\hline GDP & -0.54 & 1.0 & & & & & \\
\hline Democracy & -0.50 & 0.37 & 1.0 & & & & \\
\hline Ethnicity & 0.64 & -0.42 & -0.27 & 1.0 & & & \\
\hline Language & 0.57 & -0.36 & -0.29 & 0.74 & 1.0 & & \\
\hline GINI & 0.38 & -0.24 & 0.02 & 0.32 & 0.12 & 1.0 & \\
\hline Urban & -0.64 & 0.60 & 0.42 & -0.37 & -0.47 & -0.11 & 1.0 \\
\hline Catholic & -0.23 & 0.19 & 0.35 & -0.11 & -0.25 & 0.22 & 0.37 \\
\hline Muslim & 0.39 & -0.12 & -0.42 & 0.18 & 0.16 & -0.21 & -0.18 \\
\hline Christian & -0.24 & -0.05 & 0.10 & -0.10 & -0.01 & -0.06 & 0.03 \\
\hline Hindu & 0.07 & -0.001 & 0.08 & 0.03 & 0.13 & -0.07 & -0.18 \\
\hline Jewish & -0.03 & 0.06 & 0.09 & -0.04 & 0.04 & 0.01 & 0.15 \\
\hline $\begin{array}{l}\text { East Asian } \\
\text { Religions }\end{array}$ & -0.01 & -0.01 & -0.19 & -0.09 & -0.02 & -0.03 & -0.20 \\
\hline $\begin{array}{l}\text { Traditional } \\
\text { Religions/ } \\
\text { Atheism }\end{array}$ & 0.25 & -0.09 & -0.09 & 0.22 & 0.17 & 0.15 & -0.22 \\
\hline $\begin{array}{l}\text { Industrialized } \\
\text { Nations }\end{array}$ & -0.60 & 0.56 & 0.41 & -0.40 & -0.26 & -0.39 & 0.46 \\
\hline Soviet Bloc & -0.35 & -0.07 & 0.01 & -0.11 & -0.09 & -0.40 & 0.06 \\
\hline Middle East & 0.09 & 0.01 & -0.21 & -0.05 & -0.15 & -0.09 & 0.07 \\
\hline Africa & 0.66 & -0.50 & -0.26 & 0.56 & 0.62 & 0.30 & -0.47 \\
\hline $\begin{array}{l}\text { Latin } \\
\text { America }\end{array}$ & -0.04 & 0.04 & 0.26 & -0.04 & -0.37 & 0.54 & 0.30 \\
\hline South Asia & 0.11 & -0.01 & -0.07 & 0.01 & 0.11 & -0.07 & -0.29 \\
\hline East Asia & -0.09 & 0.20 & 0.09 & -0.16 & -0.12 & -0.08 & 0.13 \\
\hline $\begin{array}{l}\text { South East } \\
\text { Asia }\end{array}$ & 0.06 & 0.03 & 0.01 & 0.03 & 0.15 & 0.04 & -0.10 \\
\hline
\end{tabular}

Indeed, in order to better demonstrate the strength of the correlation between a country's

economy and its disempowerment of women, Graph 1 plots a clear negative correlation between

female disempowerment and GDP, such that that the world's wealthiest countries appear, almost

without exception, to be the places where women are most empowered. Even so, it is not yet clear what additional variables could be affecting this relationship. This question can only be properly addressed in a multivariate statistical analysis. 


\section{Graph 1: Correlation of Disempowerment with GDP, by Country Codes}

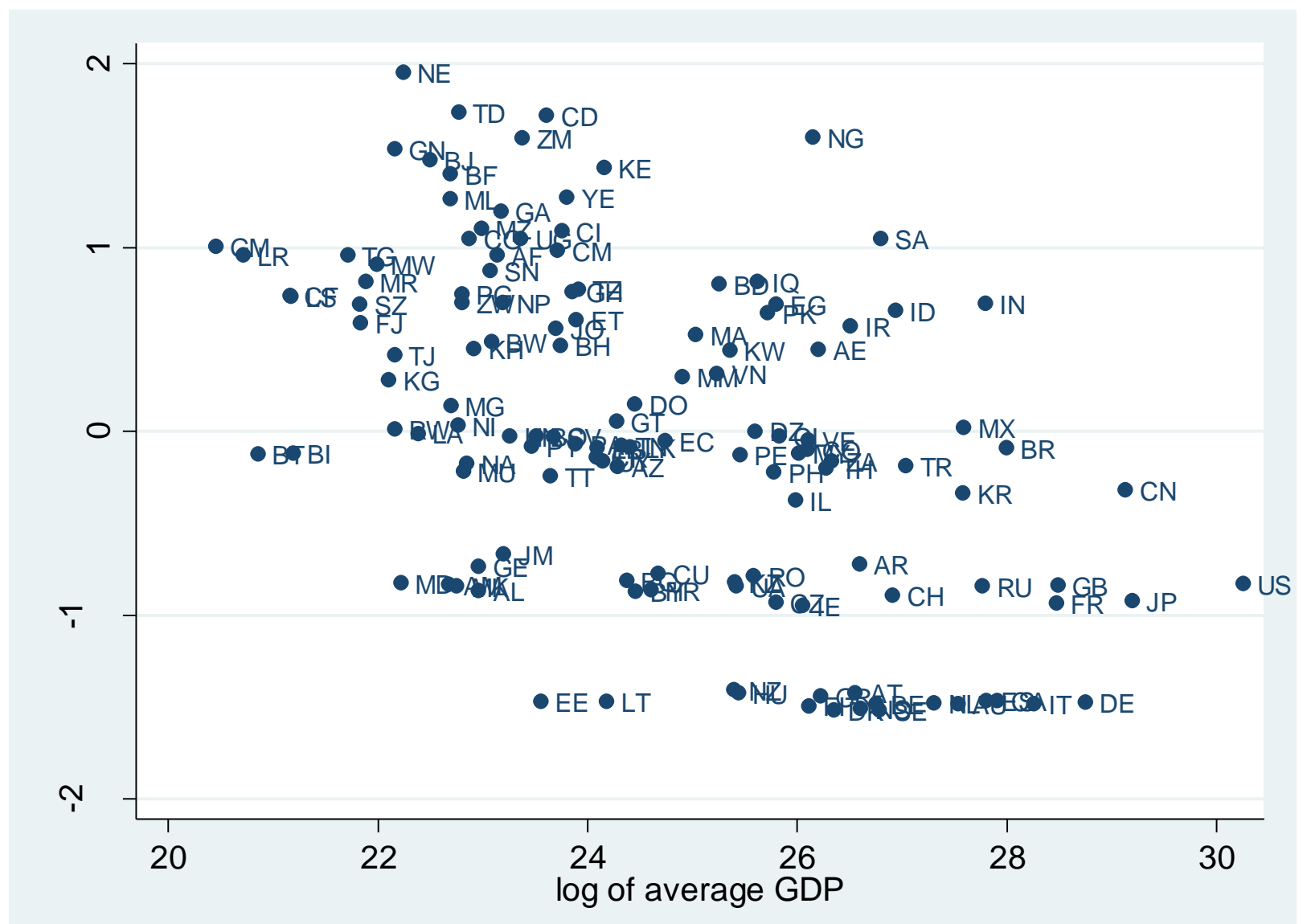

Multivariate Analysis

The results for a multivariate analysis reveal a mix of supported hypotheses and unexpected findings. The models are ordered in the same way as the hypotheses were presented earlier in this essay, beginning with the baseline model for female disempowerment and national wealth, and moving forward with the addition of each subsequent control. Also, the significant coefficients are presented in bold, with the p-values reported in parentheses below each number. 
Table 5. Multivariate Results for Disempowerment

\begin{tabular}{|c|c|c|c|c|c|c|c|c|}
\hline & Model 1 & Model 2 & Model 3 & Model 3A & Model 4 & Model 5 & Model 6 & Model 7 \\
\hline $\begin{array}{l}\text { GDP } \\
\text { (logged) }\end{array}$ & $\begin{array}{l}-.2241552 \\
(0.000)\end{array}$ & $\begin{array}{l}.174237 \\
(0.000)\end{array}$ & $\begin{array}{l}.0094426 \\
(0.724)\end{array}$ & $\begin{array}{l}-.0311512 \\
(0.264)\end{array}$ & $\begin{array}{l}-.0994453 \\
(0.001)\end{array}$ & $\begin{array}{l}-.1139301 \\
(0.000)\end{array}$ & $\begin{array}{l}-.0897776 \\
(0.001)\end{array}$ & $\begin{array}{l}-.0260462 \\
(0.368)\end{array}$ \\
\hline Democracy & & $\begin{array}{l}-.0577049 \\
(0.000)\end{array}$ & $\begin{array}{l}-.0248193 \\
(0.007)\end{array}$ & $\begin{array}{l}-.0423999 \\
(0.000)\end{array}$ & $\begin{array}{l}-.0513127 \\
(0.000)\end{array}$ & $\begin{array}{l}-.0330972 \\
(0.004)\end{array}$ & $\begin{array}{l}-.0322561 \\
(0.006)\end{array}$ & $\begin{array}{l}-.0279109 \\
(0.010)\end{array}$ \\
\hline $\begin{array}{l}\text { Ethnic } \\
\text { Diversity }\end{array}$ & & & & & $\begin{array}{l}1.139511 \\
(0.001)\end{array}$ & $\begin{array}{l}.9361716 \\
(0.003)\end{array}$ & $\begin{array}{l}.5754168 \\
(0.081)\end{array}$ & $\begin{array}{l}.7208855 \\
(0.017)\end{array}$ \\
\hline $\begin{array}{l}\text { Linguistic } \\
\text { Diversity }\end{array}$ & & & & & $\begin{array}{l}.4710119 \\
(0.092) \\
\end{array}$ & $\begin{array}{l}.4605557 \\
(0.088) \\
\end{array}$ & $\begin{array}{l}.5972973 \\
(0.024) \\
\end{array}$ & $\begin{array}{l}.3107742 \\
(0.215) \\
\end{array}$ \\
\hline Catholic & & & & & & $\begin{array}{l}.5180304 \\
(0.362)\end{array}$ & $\begin{array}{l}.3549842 \\
(0.501)\end{array}$ & $\begin{array}{l}.3668718 \\
(0.452)\end{array}$ \\
\hline Muslim & & & & & & $\begin{array}{l}.925806 \\
(0.113)\end{array}$ & $\begin{array}{l}1.027545 \\
(0.059)\end{array}$ & $\begin{array}{l}.9084004 \\
(0.071)\end{array}$ \\
\hline Christian & & & & & & $\begin{array}{l}.2499711 \\
(0.662)\end{array}$ & $\begin{array}{l}.2246442 \\
(0.672)\end{array}$ & $\begin{array}{l}.1815765 \\
(0.711)\end{array}$ \\
\hline Hindu & & & & & & $\begin{array}{l}.9362227 \\
(0.154) \\
\end{array}$ & $\begin{array}{l}.9909207 \\
(0.104) \\
\end{array}$ & $\begin{array}{l}.6165681 \\
(0.278) \\
\end{array}$ \\
\hline Jewish & & & & & & $\begin{array}{l}.6218889 \\
(0.435) \\
\end{array}$ & $\begin{array}{l}.4156964 \\
(0.574) \\
\end{array}$ & $\begin{array}{l}.7843708 \\
(0.255) \\
\end{array}$ \\
\hline $\begin{array}{l}\text { East Asian } \\
\text { Religions }\end{array}$ & & & & & & $\begin{array}{l}.479682 \\
(0.427) \\
\end{array}$ & $\begin{array}{l}.4338484 \\
(0.441)\end{array}$ & $\begin{array}{l}.1478721 \\
(0.778)\end{array}$ \\
\hline $\begin{array}{l}\text { Atheism and } \\
\text { Traditional } \\
\text { Religions } \\
\end{array}$ & & & & & & $\begin{array}{l}1.078062 \\
(0.074)\end{array}$ & $\begin{array}{l}.8961113 \\
(0.116)\end{array}$ & $\begin{array}{l}.6493118 \\
(0.219)\end{array}$ \\
\hline Inequality & & & & & & & $\begin{array}{l}.0326114 \\
(0.000)\end{array}$ & $\begin{array}{l}.031077 \\
(0.000)\end{array}$ \\
\hline Urbanization & & & & & & & & $\begin{array}{l}-.0134141 \\
(0.000) \\
\end{array}$ \\
\hline $\begin{array}{l}\text { Industrialized } \\
\text { Nations }\end{array}$ & & & $\begin{array}{l}-1.074919 \\
(0.000)\end{array}$ & & & & & \\
\hline Soviet Bloc & & & $\begin{array}{l}-.6821857 \\
(0.006)\end{array}$ & $\begin{array}{l}.0780526 \\
(0.635) \\
\end{array}$ & & & & \\
\hline Middle East & & & $\begin{array}{l}.3342674 \\
(0.146) \\
\end{array}$ & $\begin{array}{l}1.003692 \\
(0.000) \\
\end{array}$ & & & & \\
\hline Africa & & & $\begin{array}{l}.9421774 \\
(0.000)\end{array}$ & $\begin{array}{l}1.626242 \\
(0.000)\end{array}$ & & & & \\
\hline $\begin{array}{l}\text { Latin America } \\
\text { and Caribbean }\end{array}$ & & & $\begin{array}{l}.0088444 \\
0.972 \\
\end{array}$ & $\begin{array}{l}.8246172 \\
(0.000) \\
\end{array}$ & & & & \\
\hline South Asia & & & $\begin{array}{l}.4880382 \\
(0.086) \\
\end{array}$ & $\begin{array}{l}1.223337 \\
(0.000) \\
\end{array}$ & & & & \\
\hline East Asia & & & $\begin{array}{l}.3967799 \\
(0.329) \\
\end{array}$ & $\begin{array}{l}.5275856 \\
(0.138) \\
\end{array}$ & & & & \\
\hline $\begin{array}{l}\text { South-East } \\
\text { Asia and } \\
\text { Pacific Islands } \\
\end{array}$ & & & $\begin{array}{l}.3407837 \\
(0.236)\end{array}$ & $\begin{array}{l}1.117051 \\
(0.000)\end{array}$ & & & & \\
\hline Constant & 5.517483 & 4.52092 & .2549867 & .1051846 & 1.938732 & 1.714934 & -.0119452 & -.679456 \\
\hline $\begin{array}{l}\text { No. of } \\
\text { observations }\end{array}$ & 130 & 130 & 130 & 130 & 126 & 126 & 114 & 114 \\
\hline R-squared & 0.2683 & 0.3965 & 0.7705 & 0.7395 & 0.5710 & 0.6552 & 0.7239 & 0.7667 \\
\hline
\end{tabular}


Happily, the results of the first model demonstrate that GDP has a strong, negative effect upon disempowerment. Indeed, as GDP rises by one factor of ten, the index score for disempowerment decreases by 0.224 . This is roughly equivalent to the difference in index scores between Iran and Vietnam, with Iran claiming the higher disempowerment score of 0.570 and Vietnam claiming a score of 0.312. More specifically, this first model shows that a higher GDP is associated with lower adolescent birth rates, more women in parliament, a smaller education gap between men and women, and more expansive family and property rights for women.

The second model aims to test the strength of the relationship from the first model. With the inclusion of democracy as a control variable, this model demonstrates that an increase in GDP still has a significant negative effect upon female disempowerment, decreasing the index score by 0.174 . This amounts to the difference in index scores for Argentina and Ireland, with Argentina claiming the higher disempowerment score of -0.73 and Ireland scoring a -0.95 . What is more, this coefficient is roughly three times the coefficient for democracy itself, which seems to indicate that the explanatory power of GDP is greater than that of democracy when it comes to female disempowerment.

Next, the third model incorporates a battery of regional dummy variables into the analysis, to determine to what degree the treatment of women is dictated by regional idiosyncrasies. As the results reveal, region does appear to be a powerful predictor of female disempowerment. Indeed, the significance of GDP disappears in this context, and the dummies for industrialized nations, the Soviet bloc and Africa take its place in terms of significance, although the remaining regions have no significant effect on disempowerment.

However, Model 3A brings into the question the reliability of the conclusions drawn from the third Model, by excluding the single regional category of "industrialized nations." This exclusion is made because of concerns over the high level of correlation (roughly 50\%, as displayed in Table 4) between 
this particular dummy variable and a country's GDP. In other words, because of this high correlation, the inclusion of the dummy for industrialized nations in the third model, intuitively enough, weakens the explanatory power of GDP, as is evidenced by its exclusion in this alternate model. After all, the variable was created in an effort to unify culturally similar nations, including Europe, Australia, the United States and Canada. But, in doing so, the variable runs the risk of simply aggregating wealthy countries. Indeed, the coefficient for GDP, once industrialized nations are excluded, is both larger and closer to statistical significance.

As such, there is reason to believe that the third model sidesteps the challenge of explaining cross-national variation in female disempowerment. In order to address this concern, the remaining models of this analysis replace these regional variables with a number of more specific variables which, together, serve to describe some of the most important identifying factors of a country's population. This move to replace regional specificities with operationalized variables has precedence, particularly in the work of Przeworksi and Teune. It is with this goal of looking past the "proper names" of regions, and identifying the more specific "variable names" underlying regional differences that this analysis proceeds with the remaining models. ${ }^{43}$

First among these more specific variables is diversity. This is measured using both ethnic and linguistic diversity. In Model number 4, these diversity variables are added to the basic model, replacing the regional variables from the third model. It is worth noting that the diversity data is missing data for four countries included in the earlier models, specifically Yemen, Rwanda, El Salvador and Cuba. Nonetheless, with these variables added into the basic model, along with democracy, the significance of GDP returns with a coefficient of -0.09 . This is equivalent to the difference in index scores between Saudi Arabia, at 1.044, and Liberia, at 0.958 . However, it is interesting to note that only ethnic diversity

\footnotetext{
${ }^{43}$ Przeworski, Adam, and Henry Teune. The Logic of Comparative Social Inquiry. New York: Wiley-Interscience,
} 1970. 
has a significant effect upon female disempowerment. Linguistic diversity does not appear to carry the same weight as ethnic divisions. Even so, the high correlation between these two diversity variables, as shown in Table 4, means that no argument can definitively be made for a distinction between ethnic and linguistic effects upon female disempowerment. Rather, the combination of these two variables serves to support the hypothesis which predicts more disempowerment in a more diverse society.

The next model, Model 5, incorporates dummy variables for religion as an additional variable used to replace region. The results show that GDP maintains both its sign and significance, with a tenfold increase in GDP leading to a decrease of 0.114 in the disempowerment index. In practical terms, this is the difference in index scores between Iraq, at .812, and Nepal at .698. What is more, none of the religion variables prove to be significant in their own right, which goes to support the hypothesis stating that the predominant religion of a country has no direct effect upon the level of female empowerment within that country. This finding holds true, even with the inclusion of further variables in the final remaining models.

The penultimate model of this analysis adds economic inequality to the model of female disempowerment. As Model 6 demonstrates, the effect of GDP on the dependent variable still holds, with a decrease of 0.09 for every tenfold increase in GDP. In concrete terms, this coefficient is equal to the difference in index scores for France, at -0.936, and Russia, at -.846. In addition, ethnic diversity falls away from significance, in favor of linguistic diversity, which once again reminds the reader of the high degree of similarity between the two diversity variables. It also goes to show that economic inequality contributes to female disempowerment, just as this essay has theorized. It should also be noted that several more countries drop out of the analysis with the inclusion of this variable. ${ }^{44}$ Indeed, there does seem to be a slight regional pattern in terms of which countries have no reported score for inequality,

\footnotetext{
${ }^{44}$ Missing countries: Algeria, Afghanistan, Bahrain, South Korea, Kuwait, Lebanon, Myanmar, New Zealand, Saudi Arabia, Trinidad and Tobago, United Arab Emirates, Zimbabwe
} 
with six of the missing countries form the Middle East. However, several economically successful countries are also missing data on this measure, including New Zealand and South Korea. As such, there does not appear to be any substantive reason for concern when it comes to this missing data. ${ }^{45}$

The final model includes one more variable in the stead of regional distinctions. This variable is the average level of urbanization over the past fifteen years. However, this last model shows a surprising result: with the inclusion of urbanization, the impact of GDP on female disempowerment fades away. Democracy, ethnic diversity and inequality all maintain their significance, and an increase of one percent in urbanization leads to a 0.013 decrease in female disempowerment. This is equal to the difference between the index scores for Mexico, at 0.018 , and Rwanda, at 0.009 . It is not immediately clear why this might be the case, although it may be related to the high level of correlation between GDP and urbanization (recall Table 1), with richer countries boasting more urbanized populations. Nonetheless, it is with confidence in the results of each of the preceding models that this analysis concludes by reiterating the importance of total, national GDP in determining a country's level of female disempowerment.

\section{Endogeneity}

Before concluding, this analysis embarked upon one last phase of statistical analysis. The goal was to determine whether female empowerment should be characterized as a cause or a consequence of the rise in a country's GDP. In an attempt to separate this direction of causation, the final table of this essay displays the results of a new set of regression analyses that feature alternate time periods in

\footnotetext{
${ }^{45}$ When this model is analyzed further, and the five components of the index are included as dependent variables in separate models, the independent variables from this analysis only have a significant effect on two of these five components: adolescent birth rate, and women's rights in family law. And, while these results are not worth reporting in the main text, these lackluster results do appear to demonstrate quite effectively that the index compiled for this analysis captures something more than just the effect of its individual components, something close to the amorphous idea of "disempowerment."
} 
modern history. Each of the models represents a new five year time period spanning back to 1970. In other words, when added together, the first three models span the same fifteen year time period included in the initial analysis, but broken into five year increments. However, in each of these models, the disempowerment data remains the same, capturing a snapshot of the global status of women from 2000-2015. Similarly, the same independent variables included in Model 6 of Table 5 are carried over into these new models, which no modifications for time. Model 6 is chosen because the variables of this model are the most theoretically sound and statistically inclusive of any of the models from the initial analysis. The inclusion and comparison of each of these models is undertaken in the hope of determining whether the link between development and female empowerment begins with development, or with female empowerment.

Tracing the trend across these nine models, six of the models followed the expected pattern, with an increase in the effect of GDP on disempowerment as the figures for GDP go further back in time. Models 10, 11 and 14 break from the pattern, with a slight decrease in the coefficient, rather than the expected increase. However, the general impression appears to be that the effect of GDP on disempowerment begins some time before the present day, with the strongest effect on modern disempowerment coming the measure for GDP from 1970-1975. This supports the hypothesis that GDP is the cause of disempowerment, rather than disempowerment serving as the cause of a lagging in GDP. And, while these models only represent a rudimentary, yet worthwhile, attempt to untangle the direction of causation between these two variables, this brief analysis has still demonstrated the potential for endogeneity, between national poverty and female disempowerment, which has gone unaddressed in the literature. 
Table 6. Lagged GDP Results for Disempowerment

\begin{tabular}{|c|c|c|c|c|c|c|c|c|c|}
\hline & Model 8 & Model 9 & Model 10 & Model 11 & Model 12 & Model 13 & Model 14 & Model 15 & Model 16 \\
\hline GDP 2010-2015 & $\begin{array}{l}-.0875485 \\
(0.001)\end{array}$ & & & & & & & & \\
\hline GDP 2005-2010 & & $\begin{array}{l}-.0939075 \\
(0.001)\end{array}$ & & & & & & & \\
\hline GDP 2000-2005 & & & $\begin{array}{l}-.0889484 \\
(0.001)\end{array}$ & & & & & & \\
\hline GDP 1995-2000 & & & & $\begin{array}{l}-.0887346 \\
(0.001)\end{array}$ & & & & & \\
\hline GDP 1990-1995 & & & & & $\begin{array}{l}-.09828 \\
(0.000) \\
\end{array}$ & & & & \\
\hline GDP 1985-1990 & & & & & & $\begin{array}{l}-.1105556 \\
(0.000)\end{array}$ & & & \\
\hline GDP 1980-1985 & & & & & & & $\begin{array}{l}-.1061779 \\
(0.001)\end{array}$ & & \\
\hline GDP $1975-1980$ & & & & & & & & $\begin{array}{l}.1332223 \\
(0.000) \\
\end{array}$ & \\
\hline GDP 1970-1975 & & & & & & & & & $\begin{array}{l}-.1440688 \\
(0.000)\end{array}$ \\
\hline Democracy & $\begin{array}{l}-.0332686 \\
(0.004)\end{array}$ & $\begin{array}{l}-.0314002 \\
(0.007) \\
\end{array}$ & $\begin{array}{l}-.0307084 \\
(0.009)\end{array}$ & $\begin{array}{l}.029739 \\
(0.011) \\
\end{array}$ & $\begin{array}{l}-.0272601 \\
(0.019)\end{array}$ & $\begin{array}{l}-.0362536 \\
(0.000)\end{array}$ & $\begin{array}{l}-.0334848 \\
(0.009)\end{array}$ & $\begin{array}{l}-.0298649 \\
(0.024)\end{array}$ & $\begin{array}{l}-.02782 \\
(0.036) \\
\end{array}$ \\
\hline Ethnic Diversity & $\begin{array}{l}.5823379 \\
(0.072) \\
\end{array}$ & $\begin{array}{l}.5687137 \\
(0.077) \\
\end{array}$ & $\begin{array}{l}.5741022 \\
(0.076) \\
\end{array}$ & $\begin{array}{l}.5725274 \\
(0.077) \\
\end{array}$ & $\begin{array}{l}.5703767 \\
(0.074) \\
\end{array}$ & $\begin{array}{l}.6469468 \\
(0.003) \\
\end{array}$ & $\begin{array}{l}.6980412 \\
(0.027) \\
\end{array}$ & $\begin{array}{l}.6535875 \\
(0.032) \\
\end{array}$ & $\begin{array}{l}.6582321 \\
(0.030)\end{array}$ \\
\hline $\begin{array}{l}\text { Linguistic } \\
\text { Diversity }\end{array}$ & $\begin{array}{l}.6027485 \\
(0.023)\end{array}$ & $\begin{array}{l}.5921148 \\
(0.024)\end{array}$ & $\begin{array}{l}.5892708 \\
(0.026)\end{array}$ & $\begin{array}{l}.6012641 \\
(0.022)\end{array}$ & $\begin{array}{l}.63283 \\
(0.015)\end{array}$ & $\begin{array}{l}.6346682 \\
(0.010)\end{array}$ & $\begin{array}{l}.6259638 \\
(0.016)\end{array}$ & $\begin{array}{l}.6251199 \\
(0.014)\end{array}$ & $\begin{array}{l}.5623021 \\
(0.027)\end{array}$ \\
\hline Catholic & $\begin{array}{l}.3741914 \\
(0.479)\end{array}$ & $\begin{array}{l}.3396768 \\
(0.517)\end{array}$ & $\begin{array}{l}.3415234 \\
(0.517)\end{array}$ & $\begin{array}{l}.3373194 \\
(0.522)\end{array}$ & $\begin{array}{l}.3798334 \\
(0.464)\end{array}$ & $\begin{array}{l}.4237238 \\
(0.386)\end{array}$ & $\begin{array}{l}.4242985 \\
(0.402)\end{array}$ & $\begin{array}{l}.4052835 \\
(0.404)\end{array}$ & $\begin{array}{l}.428718 \\
(0.376)\end{array}$ \\
\hline Muslim & $\begin{array}{l}1.048524 \\
(0.055)\end{array}$ & $\begin{array}{l}1.007815 \\
(0.063)\end{array}$ & $\begin{array}{l}1.01061 \\
(0.064)\end{array}$ & $\begin{array}{l}.9867528 \\
(0.070)\end{array}$ & $\begin{array}{l}1.022948 \\
(0.056)\end{array}$ & $\begin{array}{l}1.053719 \\
(0.037)\end{array}$ & $\begin{array}{l}1.060951 \\
(0.043)\end{array}$ & $\begin{array}{l}1.09169 \\
(0.032)\end{array}$ & $\begin{array}{l}1.111268 \\
(0.028)\end{array}$ \\
\hline Christian & $\begin{array}{l}.2438787 \\
(0.646)\end{array}$ & $\begin{array}{l}.2095175 \\
(0.691)\end{array}$ & $\begin{array}{l}.2089612 \\
(0.694)\end{array}$ & $\begin{array}{l}.2074453 \\
(0.695)\end{array}$ & $\begin{array}{l}.2596616 \\
(0.618)\end{array}$ & $\begin{array}{l}.3734684 \\
(0.448) \\
\end{array}$ & $\begin{array}{l}.3714532 \\
(0.468)\end{array}$ & $\begin{array}{l}.394127 \\
(0.423)\end{array}$ & $\begin{array}{l}.42576999 \\
(0.385) \\
\end{array}$ \\
\hline Hindu & $\begin{array}{l}1.016602 \\
(0.097) \\
\end{array}$ & $\begin{array}{l}.9664693 \\
(0.111) \\
\end{array}$ & $\begin{array}{l}.9791798 \\
(0.109) \\
\end{array}$ & $\begin{array}{l}.9680929 \\
(0.112)\end{array}$ & $\begin{array}{l}.938789 \\
(0.117) \\
\end{array}$ & $\begin{array}{l}.8955416 \\
(0.112) \\
\end{array}$ & $\begin{array}{l}.8832404 \\
(0.131)\end{array}$ & $\begin{array}{l}.8507928 \\
(0.129) \\
\end{array}$ & $\begin{array}{l}1.237855 \\
(0.039)\end{array}$ \\
\hline Jewish & $\begin{array}{l}.4340633 \\
(0.558) \\
\end{array}$ & $\begin{array}{l}.3953572 \\
(0.590) \\
\end{array}$ & $\begin{array}{l}.4143763 \\
(0.575) \\
\end{array}$ & $\begin{array}{l}.4060887 \\
(0.582) \\
\end{array}$ & $\begin{array}{l}.3850308 \\
(0.595) \\
\end{array}$ & $\begin{array}{l}.4119522 \\
(0.546) \\
\end{array}$ & $\begin{array}{l}.3867405 \\
(0.584) \\
\end{array}$ & $\begin{array}{l}.3336585 \\
(0.621) \\
\end{array}$ & $\begin{array}{l}.38672 \\
(0.566) \\
\end{array}$ \\
\hline $\begin{array}{l}\text { East Asian } \\
\text { Religions }\end{array}$ & $\begin{array}{l}.4566111 \\
(0.419)\end{array}$ & $\begin{array}{l}.4109042 \\
(0.463)\end{array}$ & $\begin{array}{l}.4226125 \\
(0.453)\end{array}$ & $\begin{array}{l}.4235178 \\
(0.452)\end{array}$ & $\begin{array}{l}.4211967 \\
(0.446)\end{array}$ & $\begin{array}{l}.2446236 \\
(0.642)\end{array}$ & $\begin{array}{l}.1476005 \\
(0.789)\end{array}$ & $\begin{array}{l}.5361905 \\
(0.330)\end{array}$ & $\begin{array}{l}.7034087 \\
(0.187)\end{array}$ \\
\hline $\begin{array}{l}\text { Traditional } \\
\text { Religions/Atheism }\end{array}$ & $\begin{array}{l}.9163144 \\
(0.109)\end{array}$ & $\begin{array}{l}.880027 \\
(0.121) \\
\end{array}$ & $\begin{array}{l}.8778032 \\
(0.124)\end{array}$ & $\begin{array}{l}.8643981 \\
(0.129)\end{array}$ & $\begin{array}{l}.8741313 \\
(0.119)\end{array}$ & $\begin{array}{l}.8639807 \\
(0.102)\end{array}$ & $\begin{array}{l}.8791896 \\
(0.108)\end{array}$ & $\begin{array}{l}.845984 \\
(0.111)\end{array}$ & $\begin{array}{l}.9062479 \\
(0.087)\end{array}$ \\
\hline Inequality & $\begin{array}{l}.0329575 \\
(0.000)\end{array}$ & $\begin{array}{l}.0320931 \\
(0.000)\end{array}$ & $\begin{array}{l}.0328857 \\
(0.000)\end{array}$ & $\begin{array}{l}.0338553 \\
(0.000)\end{array}$ & $\begin{array}{l}.0297609 \\
(0.000)\end{array}$ & $\begin{array}{l}.0209628 \\
(0.003)\end{array}$ & $\begin{array}{l}.0220753 \\
(0.003)\end{array}$ & $\begin{array}{l}.0228595 \\
(0.004)\end{array}$ & $\begin{array}{l}.0220592 \\
(0.005)\end{array}$ \\
\hline $\begin{array}{l}\text { No. of } \\
\text { observations }\end{array}$ & 114 & 114 & 114 & 113 & 111 & 99 & 93 & 85 & 85 \\
\hline R-squared & 0.7225 & 0.7267 & 0.7235 & 0.7254 & 0.7276 & 0.7691 & 0.7550 & 0.7874 & 0.7893 \\
\hline Constant & -.0683584 & .1271205 & -.0899369 & -.1560544 & .1800954 & .8198271 & .6132588 & 1.184939 & 1.350612 \\
\hline
\end{tabular}

\section{Conclusions}

This analysis began with the plan of uniting two literatures. The first literature addresses the pressure poverty places on the treatment of women in poor households and neighborhoods. A second literature looks at the way in which female empowerment contributes to the further development of a national economy. However, neither literature acknowledges the potential for national poverty to serve 
as an explanation for female disempowerment. Therefore, this essay expanded the scope of the analysis to include poverty at the national level, and proposed that a reversal of the direction of causation between these two main variables might shed light on an undertheorized cause of female disempowerment.

In doing so, this analysis finds that national poverty is a significant factor when it comes to determining the level of female disempowerment within a country. Even when controlling for democracy, diversity and inequality, the results still hold. Indeed, the evidence fails to support only two of the proposed hypotheses.

First, the variables for regional identities carry notable significance in the model, contrary to expectations. However, regional dummies are, arguably, nothing more than convenient containers for clusters of theoretically relevant variables, each of which must be isolated and examined in turn. Thus, the names of regions are replaced with more specific variable names. The second challenge to the results on national poverty and female disempowerment is urbanization, and this divergence is harder to refute. Indeed, more urbanized nations appear to be more empowered, regardless of whether these countries are relatively wealthy or impoverished. This intriguing result pushes against prior expectations and would merit further exploration in future studies.

In conclusion, this analysis argues that national-level poverty leads to female disempowerment, by the creation of national cultures in which discriminatory gender norms go unquestioned and female life is systematically undervalued. In these places, survival becomes more pertinent for women than legal rights, or even education. However, an awareness of this global bias can help the literature identify other ways in which national poverty affects women uniquely, and bring the world one step closer to a status quo under which all women are allowed and encouraged to reach their full potential in every facet of their lives. 


\section{Works Cited}

Abramo, Laís, and María Elena Valenzuela. "Women's labour force participation rates in Latin America." International Labour Review 144.4 (2005): 369-400.

Alesina, Alberto, Arnaud Devleeschauwer, William Easterly, Sergio Kurlat, and Romain Wacziarg. 2003. "Fractionalization". Journal of Economic Growth 8 (June): 155-194.

Al Rashedi, Noura, et al. "Social Marketing, Education And The Female Workforce: A Comparison Of United Arab Emirates And Kingdom Of Saudi Arabia." Middle East Journal Of Business 10.1 (2015): 3949. Business Source Complete. Web. 7 Dec. 2015.

Apodaca, Clair. "Measuring women's economic and social rights achievement." Human Rights Quarterly 20.1 (1998): 139-172.

Apps, Patricia F., and Ray Rees. "Fertility, female labor supply and public policy." (2001).

Bajracharya, Ashish, and Sajeda Amin. "Microcredit And Domestic Violence In Bangladesh: An Exploration Of Selection Bias Influences." Demography 50.5 (2013): 1819-1843. EconLit with Full Text. Web. 8 Dec. 2015.

Bamiwuye, Samson Olusina, and Clifford Odimegwu. "Spousal violence in sub-Saharan Africa: does household poverty-wealth matter?." Reproductive health 11.1 (2014): 45.

Barthold, Douglas, et al. "Analyzing Whether Countries Are Equally Efficient At Improving Longevity For Men And Women." American Journal Of Public Health 104.11 (2014): 2163-2169. SPORTDiscus with Full Text. Web. 7 Dec. 2015.

Bauer, Gretchen, and Jennie E. Burnet. "Gender quotas, democracy, and women's representation in Africa: Some insights from democratic Botswana and autocratic Rwanda." Women's Studies International Forum. Vol. 41. Pergamon, 2013.

Besamusca, Janna, et al. "Working Women Worldwide. Age Effects in Female Labor Force Participation in 117 Countries." World Development 74 (2015): 123-141.

Charmes, Jacques, and Saskia Wieringa. "Measuring women's empowerment: an assessment of the gender-related development index and the gender empowerment measure." Journal of Human Development 4.3 (2003): 419-435.

Chaudhuri, Sanjukta. "A Life Course Model of Human Rights Realization, Female Empowerment, and Gender Inequality in India." World Development 52 (2013): 55-70.

Cueva Beteta, Hanny. "What is missing in measures of women's empowerment?." Journal of Human Development 7.2 (2006): 221-241.

Engelhardt, Henriette, and Alexia Prskawetz. "On the changing correlation between fertility and female employment over space and time." European Journal of Population/Revue européenne de Démographie 20.1 (2004): 35-62.

Evans, Susan. "Beyond Gender: Class, Poverty And Domestic Violence." Australian Social Work 58.1 (2005): 36-43. Academic Search Complete. Web. 8 Dec. 2015. 
Farber, Naomi, and Julie E. Miller-Cribbs. "Violence in the lives of rural, southern, and poor white women." Violence against women (2014): 1077801214535104.

Grech, Victor. "Evidence of economic deprivation and female foeticide in a United Nations global births by gender data set." Early human development 91.12 (2015): 855-858.

Gould, Georgina, and Dora Brown. "Quotas Are Not Enough To Eradicate 'Masculine' Boardrooms: The Role Of Counselling Psychology In Extending The Debate." Counselling Psychology Review 28.2 (2013): 82-90. Academic Search Complete. Web. 7 Dec. 2015.

Gül, Songül Sallan. "The role of the State in protecting women against domestic violence and women's shelters in Turkey." Women's Studies International Forum. Vol. 38. Pergamon, 2013.

Hague, Gill, Ravi K. Thiara, and Atuki Turner. "Bride-price and its links to domestic violence and poverty in Uganda: A participatory action research study." Women's Studies International Forum. Vol. 34. No. 6. Pergamon, 2011.

Kiss, Ligia, et al. "Gender-based violence and socioeconomic inequalities: Does living in more deprived neighbourhoods increase women's risk of intimate partner violence?." Social science \& medicine 74.8 (2012): 1172-1179.

Klasen, Stephan, and Dana Schuler. "Reforming The Gender-Related Development Index And The Gender Empowerment Measure: Implementing Some Specific Proposals." Feminist Economics 17.1 (2011): 1-30. EconLit with Full Text. Web. 10 Dec. 2015.

Kocacık, Faruk, Aziz Kutlar, and Feray Erselcan. "Domestic violence against women: A field study in Turkey." The Social Science Journal 44.4 (2007): 698-720.

Lincove, Jane Arnold. "Growth, girls' education, and female labor: A longitudinal analysis." The Journal of Developing Areas 41.2 (2008): 45-68.

Lynn, Richard, and Prateek Yadav. "Differences in cognitive ability, per capita income, infant mortality, fertility and latitude across the states of India." Intelligence 49 (2015): 179-185.

Malapit, Hazel Jean L., and Agnes R. Quisumbing. "What dimensions of women's empowerment in agriculture matter for nutrition in Ghana?." Food Policy 52 (2015): 54-63.

McGuire, James W. Wealth, health, and democracy in East Asia and Latin America. Cambridge University Press, 2010.

Mishra, Ankita. "Multidimensional measures of female disempowerment." Social Indicators Research 119.3 (2014): 1393-1410.

Njoh, Ambe J., and Fenda A. Akiwumi. "The impact of religion on women empowerment as a millennium development goal in Africa." Social Indicators Research 107.1 (2012): 1-18.

Owen, A. L. and You, R. (2009), Growth, Attitudes towards Women, and Women's Welfare. Review of Development Economics, 13: 134-150. doi: 10.1111/j.1467-9361.2008.00466.x 
Oztunc, Hakan, Oo Zar Chi, and Zehra Vildan Serin. "Effects Of Female Education On Economic Growth: A Cross Country Empirical Study." Educational Sciences: Theory \& Practice 15.2 (2015): 349-357. Academic Search Complete. Web. 7 Dec. 2015.

Panda, Pradeep, and Bina Agarwal. "Marital violence, human development and women's property status in India." World Development 33.5 (2005): 823-850.

Phillips, Anne. The politics of presence. Clarendon Press, 1995.

Przeworski, Adam, and Henry Teune. The Logic of Comparative Social Inquiry. New York: WileyInterscience, 1970.

Rehman, Huma, Amani Moazzam, and Nighat Ansari. "Role Of Microfinance Institutions In Women Empowerment: A Case Study Of Akhuwat, Pakistan." South Asian Studies (1026-678X) 30.1 (2015): 93111. Academic Search Complete. Web. 7 Dec. 2015.

Rivera-Rivera, Leonor, et al. "Prevalence and determinants of male partner violence against Mexican women: A population-based study." salud pública de méxico 46.2 (2004): 113-122.

Ruppanner, Leah E. "Cross-national reports of housework: An investigation of the gender empowerment measure." Social Science Research 39.6 (2010): 963-975.

Semahegn, Agumasie, and Bezatu Mengistie. "Domestic violence against women and associated factors in Ethiopia; systematic review." Reproductive health 12.1 (2015): 78.

Sen, Amartya. "More than 100 million women are missing." The New York Review of Books (1990).

Setegn, Tesfaye, Yihunie Lakew, and Kebede Deribe. "Geographic Variation and Factors Associated with Female Genital Mutilation among Reproductive Age Women in Ethiopia: A National Population Based Survey." PloS one 11.1 (2016): e0145329.

Upadhyay, Ushma D., et al. "Women's empowerment and fertility: A review of the literature." Social Science \& Medicine 115 (2014): 111-120.

Wängnerud, Lena. "Women in parliaments: Descriptive and substantive representation." Annual Review of Political Science 12 (2009): 51-69.

Wyndow, Paula, Jianghong $\mathrm{Li}$, and Eugen Mattes. "Female empowerment as a core driver of democratic development: A dynamic panel model from 1980 to 2005." World Development 52 (2013): 34-54.

York, Richard, and Shannon Elizabeth Bell. "Life satisfaction across nations: The effects of women's political status and public priorities." Social science research 48 (2014): 48-61. 